\title{
Between suffering and hope: rehabilitation from urinary incontinence as an intervening component
}

\author{
Entre o sofrimento e a esperança: a reabilitação \\ da incontinência urinária como componente interveniente
}

Rita de Cássia Altino Delarmelindo ${ }^{1}$

Cristina M aria Garcia de Lima Parada ${ }^{2}$

Rosalina A parecida Partezani Rodrigues ${ }^{3}$

Silvia Cristina M angini Bocchi ${ }^{2}$

${ }^{1}$ Centro de Ciências Biológicas eda Saúde, Universidadedo Sagrado Coração. R. Irmã Armeinda 10-50, Jd Brasil. 17044-160 Bauru SP.

altino.blv@terra.com.br

${ }^{2}$ Departamento de

Enfermagem, Faculdade de

M edicina deBotucatu,

UniversidadeEstadual

Paulista.

${ }^{3}$ Escola de Enfermagem de

Ribeirão Preto, USP.
Abstract This is a qualitative study seeking to understand Brazilian women's experience of urinary incontinence (UI) and design a representative theoretical model for the experience. Theore tical saturation occurred after analysis of the $18^{\text {th }}$ non-directive interview in accordance with Grounded Theory. Two phenomena emerged: living with the challenges of $\mathrm{UI}$ and experiencing the hope and disappointment of rehabilitation from UI. U pon realignment of the components, the core category emerged, namely: between suffering and hope - rehabilitation from urinary incontinence as an intervening component. From the analysis in light of symbolic interactionism, pregnancy and vaginal birth were observed to be symbols of women's vulnerability to the suffering from living with the moral and physio-psychosocial challenges of UI. It is also inferred that thelack of consideration of the U nified Health System (SUS) in investing in the process of rehabilitation from UI may be having a negative effect on the incentive programs for promoting vaginal birth. M ost of all, it reveals the ongoing suffering of women with $\mathrm{UI}$, most of whom do not have access to rehabilitation due to the lack of programs geared to the real needs of these users of the U nified $\mathrm{H}$ ealth System.

Key words Urinary incontinence, Women's he alth, Life changing events, Psychosocial effects of the disease, Q ualitative research
Resumo Estudo de natureza qualitativa com os objetivos de compreender a experiência de muIheres com incontinência urinária e elaborar um modelo teórico representativo da mesma. A saturação teórica se deu mediante a análise da $18^{a}$ entrevista não diretiva, segundo a Teoria Fundamentada nos Dados. Emergiram dois fenômenos: convivendo com os desafios da Incontinência U rinária (IU) e vivenciando a esperança e a desilusão de reabilitar-seda IU. D o re-alinhamento dos componentes provindos dos fenômenos emergiu a categoria central, denominada: entre 0 sofrimento e a esperança - 0 apoio e 0 acesso a reabilitação da IU como componente interveniente. Da análise à luz do Interacionismo Simbólico verificou-se que a gravidez e o parto vaginal emergem como símbolos de vulnerabilidade da mulher ao sofrimento de conviver com o desafio moral efisiopsicossocial da IU. Bem como a inferência de que a desconsideração do Sistema Ú nico de Saúde (SUS) com investimentos no processo de reabilitação da IU possa estar fragilizando os próprios programas de incentivo ao parto vaginal. A ponta a perpetuação do sofrimento da mulher com a IU, que na maioria não tem acesso à reabilitação por falta de programas voltados às reais necessidades dessas usuárias do SUS.

Palavras-chave Incontinência urinária, Saúde da mulher, Acontecimentos que mudam a vida, Efeitos psicossociais da doença, Pesquisa qualitativa 
Introduction

Urinary Incontinence (UI) and Lower Urinary Tract Dysfunction (LUTD) areuniversal and epidemiologically significant problems. They are among the three major health problems worldwide, following heart diseases and cancer ${ }^{1}$, and they affect a higher number of femalesthan males².

The International Continence Society (ICS) defines $\mathrm{UI}$ as any involuntary leakage of urine, and relevant factors must beconsidered, such as: type, frequency, severity, precipitating agents of social impact, effects on hygiene and quality of life, necessary measures to control leakage if an individual, caregiver or partner seeks or wants help from health care professionals to solve the problem ${ }^{1}$.

According to ICS, IU can be classified as: stress incontinence (SI), urge incontinence (UI), mixed (MI), continuous, situational and nocturnal enuresis ${ }^{1}$. It is considered to bea public health problem, and specific public health policies are necessary for its management, since it causes impact on thelife conditions of women experiencing it, thus becoming a condition that is difficult to copewith.

Based on the above, it can be stated that, in order to work on UI prevention and rehabilitation, technically and scientifically skilled professionals are necessary. However, educational establishments most often relegate this topic to a second level of importance, which makesindividuals affected by UI livein invisibility and contributes to the lack of potent public health policies.

Current studies on UI, including new guidelines from the European Association of Urology, suggest, as a first recommendation, the use of less invasive therapies and then proceeding to other moreinvasivetreatments in a gradual scale. Diagnostic evaluation and therapeutic interventions aregrouped into two levels: initial manage ment and specialized management.

The initial treatment includes measures that are usually instituted in the first contact with the patient, established with basis on her clinical history and physical examination and by using basic diagnostic tests in order to excludeunderlying conditions or diseases, such as urinary tract infection. This first contact with the client can be made by an expert incontinencenurse, a primary care doctor or even a specialist. The majority of times, the recommended treatment will be conservative, namely, pharmacological and or physiotheraeutic ${ }^{3}$.

Specialized management applies to patients for whom a diagnosis could not beestablished in theinitial management level. Thesymptoms suggest a more complex or severe condition that re quires diagnostic evaluation and/or specific treatment options, and urodynamic studies are often necessary to establish a physiopathology-based diagnosis. Treatment includes invasive interventions and surgery ${ }^{3}$.

Scientific articles on UI incidence arestill little frequent and, when they are available, there is great rate variation, which is probably due to differences in the diagnostic definition for this pathology. Studies conducted on females showed a variation ranging from $2 \%$ to $11 \%$ by Wennberg et al. ${ }^{4}$ and from $5 \%$ to $69 \%$ by Long et al. ${ }^{5}$ and Altman et al. ${ }^{6}$. Pregnancy is related to the problem: its occurrence is more common in this period and complete remission rates, which vary from zero to $13 \%$, are also more common after pregnancy.

The greatest $\mathrm{UI}$ occurrence in females of all ages, that is, older, younger and middle-aged, results from numerous factors, especially pregnancy, childbirth and menopausal hormonal changes. Heredity, smoking, obesity, having undergone gynecologic surgery, intestinal constipation, having chronic diseases, using certain drugs, consuming caffeine and doing certain types of physical exercises are also risk factors for $\mathrm{UI}^{7}$, as well as are various physiopathological and situational processes ${ }^{8}$.

In face of the relevance of the problem and the lack of epidemiological and qualitative studies exploring Brazilian women's experience of the disease, the following question is asked: how is these women's experienceconfigured? Such question is especially relevant when the fact that the country is going through a process of population ageing is taken into account.

In order to answer the abovementioned question, this study was conducted with the purpose to understand the experience of women with $\mathrm{UI}$ and to design a representative theoretical model for such experience, aiming at furthering thecomprehension of the object, given the fact that studies using the theoretical-methodological frame work chosen have not been found.

\section{Method}

This qualitative study was conducted after approval by the Research Ethics Committee (OL 048/06) and after informed consent was obtained for participation from women over 40 years old. They wereusers of a physiotherapy clinic installed 
on the campus of Sagrado Coração University Bauru, São Paulo, Brazil, which renders services to the Unified Public Health System (SUS).

The age range over 40 years was intentionally selected, since the literature reports higher $\mathrm{U} I$ incidencein older women generally from climacterium and menopause?

Data were collected by one of the researchers from 2007 to 2009 by means of non-directive interviews and using the following guiding questions: What has your experience of UI been like?

The interviews were audio-taped and conducted on a site that was chosen by the players, whose privacy and anonymity in relation to the information provided were ensured. U pon completion, theexperiences werefully transcribed and submitted to manual analysis performed by the researchers according to the methodological framework based on the Grounded Theory ${ }^{9}$.

The Grounded Theory derives from data collected and analyzed systematically by means of an investigation process. In this method, the datacollection, analysisand theory- elaboration phases are intrinsic, which allows for in-depth understanding of the players' experience. The process comprises four steps: 1. M icroanalysis: line forline detailed analysis, which is required to generate initial categories with their properties and dimensions, suggesting relations between them and a combination with open and axial coding; 2. Open coding: analytical process by which concepts as well as their properties and dimensions are identified based on the data. A concept is the abstract representation of an event, object or action/interaction that an investigator identifies as being significant in the data and which, in turn, represent the phenomena; 3 . Axial coding: this is the process of developing and relating categories to their subcategories, around the axis of a category, that is, by connecting categories, according to their properties and dimensions in order to construct the theory. The paradigm is only a device that analysts can use to think about the relations. Although it is useful, the paradigm must never be used in a strict fashion, otherwise it be comes the end and not the means; 4. Selective coding: it corresponds to the process of integration and improvement of the theory, in which the categories areorganized around a central concept of reasons ( core category) that embraces the main categories related to it, by means of explanatory notes of the relations (memoranda), associated with other techniques, such as the use of diagrams in order to facilitate the integration process?.

\section{Results}

By following the steps proposed by this framework, theoretical saturation was achieved from the analysis of the $18^{\text {th }}$ interview with women affected by UI at the age range of 41 to 81 years. All of them were from low socioeconomic backgrounds and educational level. They had a medical diagnosis, although seven had dropped out of treatment; seven were undergoing conservative treatment, and four were in the post-conservative-treatment period.

Chart 1 presents the inductive process emerging from data analysis according to the Grounded Theory in order to facilitate the understanding of the movement undertaken by these women'sexperience.

\section{Part 1. Discovering the phenomena}

\section{Phenomenon A. Living with}

the challenges of $\mathrm{UI}$

It conveys the conceptualization of women who suffer morally and physiopsychosocially with theimpact of $\mathrm{UI}$, sinceit is a health problem that is difficult to overcomeand mostly acquired from the experience of pregnancy and vaginal delivery. This phenomenon aggregates themes: $A 1, A 2, A 3$ and $A 4$.

Theme A1. Considering IU

to be an unpleasant experience

This is thewoman's evaluation of her process of experiencing UI, based on repulsive feelings that emerge from the interaction with her personal experience and most often interrupts her project of life and the right to continuing experiencing well-being whilethe problem persists: It is very unpleasant; it has prevented me from doing what I did before..., I can't control urine output. It's not very severe incontinence, but it hinders my well-being (Player 1). I get upset for not feeling well. I get embarrassed, annoyed! [...] UI is horrible! (Player 17).

\section{Theme A2. Associating UI}

with natural delivery

$\mathrm{UI}$ is referred to by women as a natural phenomenon, associated with pregnancy, which may be experienced during the first pregnancy and aggravated with multiparity. Maternal and the offspring's weight as well as vaginal delivery are components that contribute to it: When I was pregnant with my first child, I had to have a Csection; he was very big; I had to havea $\mathrm{C}$ - section. During pregnancy, I was sometimes walking with my husband or taking a short walk, and I would 
Chart 1. Inductive process emerging from the analysis process according to the Grounded Theory.

\begin{tabular}{|c|c|c|c|}
\hline Core category & Phenomena & Themes & Categories \\
\hline \multirow{20}{*}{$\begin{array}{l}\text { Core category - } \\
\text { Between } \\
\text { suffering and } \\
\text { hope: medical } \\
\text { support and } \\
\text { access to UI } \\
\text { rehabilitation } \\
\text { at SUS as an } \\
\text { intervenient } \\
\text { component. }\end{array}$} & \multirow{11}{*}{$\begin{array}{l}\text { Phenomenon A. } \\
\text { Living with the } \\
\text { challenges of } \mathrm{UI}\end{array}$} & $\begin{array}{l}\text { Theme Al. Considering IU to } \\
\text { be an unpleasant experience }\end{array}$ & \\
\hline & & $\begin{array}{l}\text { Theme A2. Associating UI } \\
\text { with natural delivery }\end{array}$ & \\
\hline & & \multirow{4}{*}{$\begin{array}{l}\text { Theme A3. Becoming } \\
\text { apprehensive with the public } \\
\text { perception of urine }\end{array}$} & Category A3.1. Imminent need to urinate \\
\hline & & & Category A3.2. Not being able to hold urine \\
\hline & & & $\begin{array}{l}\text { Category A3.3. Seeing oneself wet in a } \\
\text { public site }\end{array}$ \\
\hline & & & $\begin{array}{l}\text { Category A3.4. Feeling afraid of being } \\
\text { perceived with urine odor }\end{array}$ \\
\hline & & \multirow{5}{*}{$\begin{array}{l}\text { Theme A4. Feeling morally } \\
\text { and physiopsychosocially } \\
\text { vulnerable }\end{array}$} & $\begin{array}{l}\text { Category A4.1. Feeling morally depressed in } \\
\text { experiencing UI }\end{array}$ \\
\hline & & & $\begin{array}{l}\text { Category A4.2. Affecting sleep and sexuality } \\
\text { needs }\end{array}$ \\
\hline & & & $\begin{array}{l}\text { Category A4.3. Emergence of UI-related } \\
\text { complications }\end{array}$ \\
\hline & & & $\begin{array}{l}\text { Category A4.4. Having health problems that } \\
\text { worsen the experience and entering psychic } \\
\text { suffering }\end{array}$ \\
\hline & & & Category A4.5. Entering psychic suffering \\
\hline & \multirow{9}{*}{$\begin{array}{l}\text { Phenomenon } \mathrm{B} \text {. } \\
\text { Experiencing the } \\
\text { hope and } \\
\text { disappointment } \\
\text { of rehabilitating } \\
\text { from UI }\end{array}$} & \multirow{5}{*}{$\begin{array}{l}\text { Theme B1. Resorting to } \\
\text { palliative strategies when } \\
\text { perspectives of improvement } \\
\text { are not seen }\end{array}$} & $\begin{array}{l}\text { Category B1.1. Not perceiving improvement } \\
\text { from conservative treatments }\end{array}$ \\
\hline & & & $\begin{array}{l}\text { Category B1.2. The doctor's discouraging } \\
\text { from surgical treatment }\end{array}$ \\
\hline & & & $\begin{array}{l}\text { Category B1.3. Experiencing UI again after } \\
\text { periods of continence }\end{array}$ \\
\hline & & & $\begin{array}{l}\text { Category B1.4. Losing hope to see oneself } \\
\text { free of the problem }\end{array}$ \\
\hline & & & $\begin{array}{l}\text { Category B1.5. Adopting palliative strategies } \\
\text { not to find oneself wet }\end{array}$ \\
\hline & & \multirow{4}{*}{$\begin{array}{l}\text { Theme B2. Seeing } \\
\text { perspectives of improvement } \\
\text { when finding possibilities of } \\
\text { treatment }\end{array}$} & $\begin{array}{l}\text { Category B2.1. Finding out that UI can be } \\
\text { treated }\end{array}$ \\
\hline & & & $\begin{array}{l}\text { Category B2.2. Perceiving UI improvement } \\
\text { by means of therapy }\end{array}$ \\
\hline & & & $\begin{array}{l}\text { Category B2.3. Seeing the possibility of } \\
\text { solving the problem by having a surgery }\end{array}$ \\
\hline & & & $\begin{array}{l}\text { Category B2.4. Feeling pleasure from } \\
\text { continence recovery }\end{array}$ \\
\hline
\end{tabular}

leak urine. [...] I have three children, and the first was rather larger than the other two. I can re member it more clearly because it was a remark- able experience (Player 1). I saw a doctor, and he told me UI was common. I've had three natural deliveries. Then, it dilates, and this happens (Player 
5). I've had two C-sections deliveries. But in my first pregnancy, I put on about 20 kilos..., then I lost a lot of weight, and it seemed to haveimproved, but after the second pregnancy UI became worse (Player 6).

Theme A3. Becoming apprehensive with the public perception of urine

It conveys the connection of four categories: imminent need to urinate, not being able to hold urine, seeing oneself wet in a public site, and feeling afraid of being perceived with urine odor. This process expresses the woman's loss of autonomy in relation to urine control, which results in the imminent perception of being wet, a fact that makes her apprehensiveand seek a toilet in anticipation to the fatality of involuntary leakage and of exuding the odor of the excretion: UI makes me nervous..., because it's more difficult to control urination, so I feel limited to going to certain places (Player 1). Dependence on the toilet is created not to find yourself wet, because the bladder is like an uncontrolled tap; even when you breathe deeply, it's not possible to hold urine. Sometimes, I'm going to the toilet in my daughter's house, and when I realize it, I've begun to leak urine in the hallway (Player 2). It's upsetting! U rine leaks after any movement you make (Player 4). I leak urine anywhere, especially when I laugh or cough (Player 8). The other day, I was out with my sister, and I had to stop and let urine go down my legs to the ground while my sister laughed a lot. Luckily, I was wearing a skirt, and it didn't show (Player 4). You becomedependent on tampons, and thisisterrible. All the time, I have the impression of being impregnated by the odor of urine, and this gives me a horrible feeling (Player 16).

Theme A4. Feeling morally and physiopsychosocially vulnerable

It results from the sequence of five categories: feeling morally depressed in experiencing UI, affecting sleep and sexuality needs, emergence of UI-related complications, having health problems that worsen the experience and entering psychic suffering. This process expresses women's perception of their experiencewith UI, which is considered to be an unpleasant event that interrupts their life plan and promotes psychic suffering in face of the continual vulnerability resulting from the embarrassment of infringing a socially established precept that only children can urinate in their clothes and wear diapers: Even though I'm older, the fear of feeling embarrassed and humiliated out of home still exists in face of the possibility of urinating near other people (Player 3). When I travel a long distance, I have to wear dia- pers as if I were a baby (Player 18). When I'm having sex, I think: ' Will I leak? So, I go to the toilet before I do it, and this is bad! (Player 6). I can't even find a partner. It's a good thing onehasn't showed up yet. Also, I can't even go out. I can't take it anymore! At night, I don't even have enough timeto get up to go to the toilet. I leave a bowl next to the bed to urinate. I have lost confidence in myself, so thisisbad for me, even for sleeping (Player 2). M y problem becomes worse at night..., some times I get up six times to change my clothes (Player 11).

Phenomenon B. Experiencing thehopeand disappointment of rehabilitating from UI

It conveys the movement experienced by women with UI, which is undertaken in face of their perception of the availability of support and access to the process of rehabilitation from the health problem shown by the doctor's efforts to refer them to conservative and surgical therapy in case the former option does not show to be effective. Otherwise, a process of suffering will emerge when they notice that the dream of re suming continenceis far from materializing. This situation is also experienced by women with chronic diseases who are deprived of clinical conditions for surgical interventions. This phenomenon gathers themes $B 1$ and $B 2$.

Theme B1. Resorting to palliative strategies when perspectives of improvement are not seen

This is a process with five categories: not perceiving improvement from conservative treatments, the doctor's discouraging from surgical treatment, experiencing $\mathrm{UI}$ again after periods of continence, losing hope to see oneself free of the problem and adopting palliative strategies not to find oneself wet. It conveys the experience of a group of women who are overwhelmed by a feeling of sadness from seeing themselves dependent on palliative strategies to control UI, in face of frustrations about conservative treatment as well as about the lack of medical support for surgical resolution: It didn't improve with physiotherapy (Player 4). The doctor does not want to operate, because besides being incontinent, I' $m$ also diabetic and hypertensive. Hetold methat I'd do better without a surgery, but this has been a great hassle (Player 18). So, what choice do I have? Should I go back to the doctor's for an operation or should I resign myself and stay like this until I die. Then, I will die and won't urinate anymore (Player 2). I have been prevented from doing activities that take a long time, such as going out, traveling, going to receptions, church services and celebrations (Player 1). 
When I go out, there must be a toilet, and that's the first thing I look for (Player 6). I have to wear tampons; it's been about two years (Player 14). Now, I have hypertension. I've taken four pills today, and I haven't taken the diuretic yet because I will have to go out (Player 3) If I drink a little more water than usual I need to go to the toilet, [...] so, I'd better not drink it (Player 7). I've lost self-confidence because I'm afraid I won't be able to hold urine, and this makesmy slep difficult, so I'vestarted to takesleeping pills (Player 2). I must be careful even about the clothes I choose. I don't wear skirts or dresses, only dark pants because when I leak urine, the color helps to hide it (Player 18). I can't even run, cough or make any physical efforts because I leak urine after any movements (Player 6).

\section{Theme $B 2$. Seeing perspectives}

of improvement when finding

possibilities of treatment

This theme gathers four subsequent categories: finding out that $U \mathrm{I}$ can betreated, perceiving UI improvement by means of therapy, seeing the possibility of solving the problem by having a surgery and feeling pleasure from continence re covery. This is a process that is experienced by another group of women who, despite perceiving improvement from conservative treatment, still hope to find medical support for surgical treatment as a possibility of becoming definitely rid of UI: I found out that $U I$ is reversible by reading a magazine. After the physi otherapy, the problem ended, but I still do exercises, and now I can laugh without leaking urine (Player 15). In my case, physiotherapy did not completely solve the problem, but the doctor has requested a surgery. I've had all the preoperative exams and tests, and it's all arranged for the operation (Player 4).

Part 2. Discovering the core category and theoretical model

Thestrategy to discover the corecategory and theoretical model wasto inter-relatethetwo phenomena, seeking to compare and analyze them in order to understand how the interaction among their components occurred. This strategy allowed for identifying the key categories re sponsible for the movement of the interactional experience of women with UI, thus making it possible to abstract the core category (Figure 1).

The theoretical model emerging was submitted to validation based on the data and showed to becapable of explaining the experiences. Later, it was analyzed in light of the theoretical framework of Symbolic Interactionism.
Four important aspects distinguish this the oretical approach from others in psychology: 1 Symbolic Interactionism creates a more active image of human beings and rejects the image of passive and determined organisms, 2 - a human being is understood as someone who acts in the present, who is influenced not only by what happened in the past, but also by what is happening at that moment, 3 - interaction is not only what is happening among people, but also something that is happening within individuals. A definition can be influenced by those with whom one interacts. It is also a result of our own definition, our interpretation of a situation, 4 - Symbolic Interactionism describes human beings as more activein their world than in other perspectives. The concepts of Symbolic Interactionism are: symbol, self, mind, sympathy, human action and social interaction ${ }^{10}$.

\section{Discussion}

By analyzing the theoretical model referring to the experience of women with UI according to Symbolic Interactionism, the movement between the contexts of suffering and hope, which is incited by the interaction with symbols that translate the possibility or not of autonomy recovery, was observed.

Such symbols are emitted by the medical professional when he/she supports or not the access to available treatments, depending on the woman's clinical conditions as well on SU S's availability to providetheconservativeand surgical treatments to individuals with UI.

When a woman interacts with symbols, such as: not improving from UI by means of conservative therapies and the doctor's discouraging surgical treatment, she defines her situation as vulnerable to continuing experiencing the moral and physiopsychosocial challengeimposed by UI.

This overload is configured as an unpleasant experience, since it interrupts the individual's life plan and leads to psychic suffering in face of her continual vulnerability, of theembarrassment from violating a socially established precept that only children can wet their clothes and wear diapers.

As a result, women becomeapprehensivewith the possibility of being perceived as having urinated in public by means of the symbols: wet clothes or urine odor.

In order to prevent the experience of being seen wet in public, women resort to palliative strategies, using attitudinal or material resources 


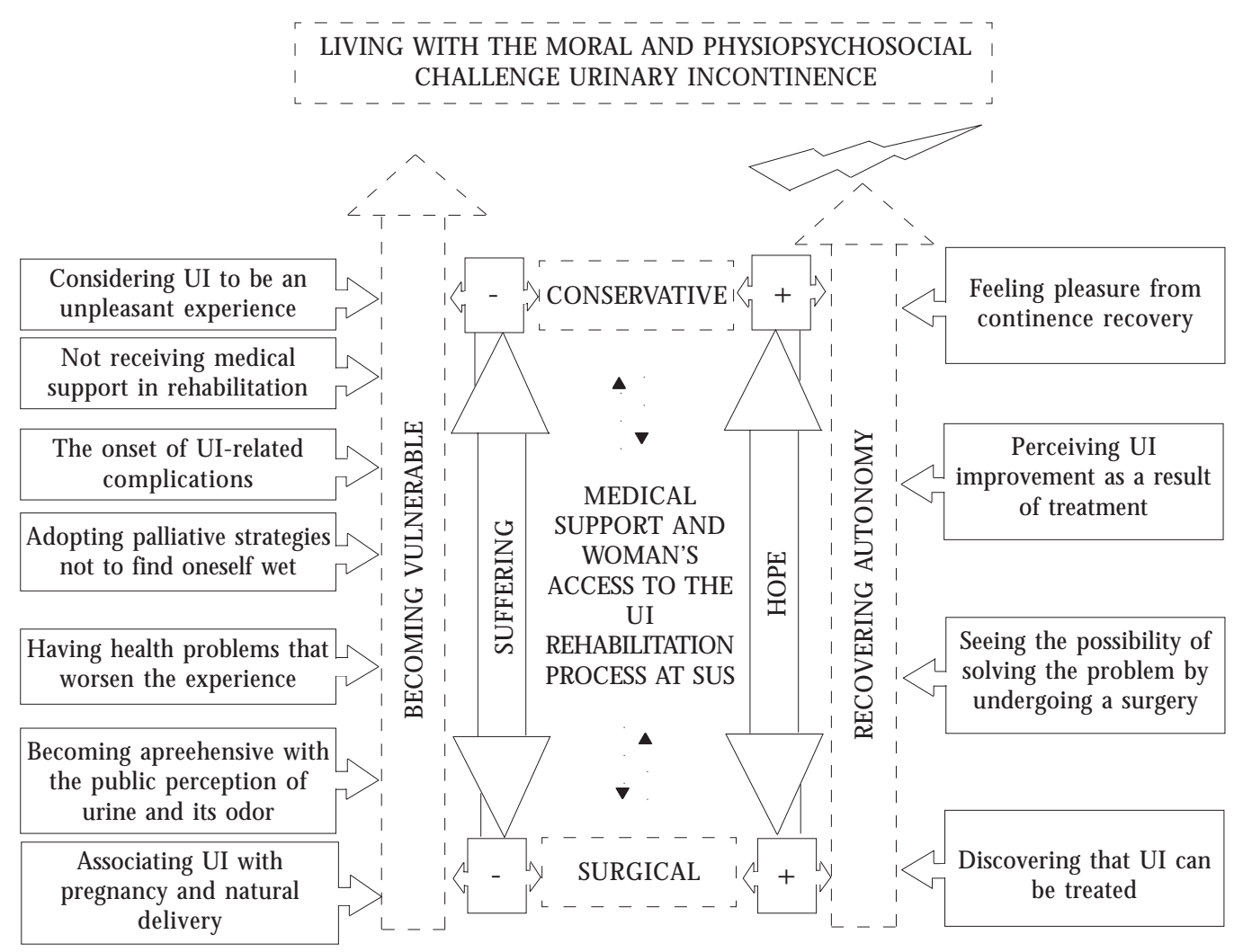

Figure 1. Core category - Between suffering and hope: medical support and access to UI rehabilitation at SUS as intervenient component.

with the purposeto minimizetheir vulnerability, particularly when they lose the expectation of rehabilitating from UI.

The strategies used affect their quality of life as they may cause social reclusion when women stop performing leisure and religious activities, especially in places wheretoilets are not available. Additionally, they may repress their sexuality for fear of leaking urine during intercourse as well as of increasing risk factors for cerebrovascular diseases, particularly for women with SAH who interrupt the use of drugs and reduce the intake of liquids so as to decrease urinary volume. Also, the use of sleep-inducing medicines may lead to dependence as they begin to be used continually. It is noteworthy that u rine collectorsincrease risk for recurrent urinary infections resulting from contact dermatitis.

As another strategy not to find themselves wet, women try to interrupt the organism's de- fensemechanisms, such as coughing, sneezing and even mood manifestations such as laughing, among other health problems: association with fecal incontinence and being exposed to stressful situations.

On the other hand, when women see the perspective of improving with conservative treatments or, if they are not effective, of a possibility to take advantage of surgical treatment, they fill themselves with hope to find support and access to the process of rehabilitation from UI, awakening hopeand pleasure in recovering continence and breaking through the challenging experience of being incontinent.

It is noteworthy that thetheoretical model (Figure 1) shows pregnancy and vaginal delivery as symbols of the vulnerability to the suffering from living with themoral and physiopsychosocial challenge oh UI. Hence, the lack of investment from SUS in the process of rehabilitation from that dis- 
ease may be contributing to the weakening of its own programs to encourage vaginal delivery.

This interpretation is supported by Symbolic Interactionism as it states that " when weinteract, we become social objects to one another; we use symbols, direct the self, engage in mental action, make decisions, change directions, shareperspectives, define reality and situations and take the other's role" ${ }^{10}$.

By analyzing the results in this study in light of the knowledge al ready produced on the object of investigation, the need for SUS to implement prevention and rehabilitation programs for women affected by UI is observed.

The fact that one of theimpacts of pregnancy and vaginal delivery is the occurrence of $U I$ after childbirth is doubtful; leading to the hypothesis that pregnancy itself may weaken the pelvic floor muscles ${ }^{11}$.

A literature review to evaluate whether caesarean deliveries protect women from UI showed that vaginal delivery alone is not sufficient for its onset, and caesarean deliveries are not sufficient to prevent it. Such statement is based on evidence showing that $50 \%$ of pregnant women only develop transitory $\mathrm{UI}^{12}$.

Chang et al. ${ }^{13}$ complement by reporting that, three months after childbirth, the prevalenceand incidence of UI were respectively $9 \%$ to $31 \%$ and $7 \%$ to $15 \%$. UI history in the prenatal period increases risk for postpartum problems, which, in turn, fosters their long-term persistence. After their first pregnancy, women who had a vaginal delivery are twofold more prone to develop UI than those who had caesarean deliveries.

In turn, the protective effect of a caesarean delivery against UI may dissipate with multiparity. It decreases as maternal age advances and when the caesarean section is performed after induction of a vaginal delivery. Nulliparousadult women may also develop UI, which can also happen to older women who have given birth or not. Approximately eight out of nine women who had their babies by vaginal deliveries suffered rupture, but only one underwent UI or prolapse surgery ${ }^{13}$.

Satisfactorily, Nygaard ${ }^{12}$ reports the need to understand the actual impact of caesarean deliveries on UI, and comparativestudies between the two delivery modalities which take into account variables such as lower urinary tract disorders and UI history prior to delivery are required.

Prospective studies have correlated episiotomy with UI incidence after labor ${ }^{13}$ as well as with fecal incontinenceincidence, especially in primiparous who used forceps or medio-lateral episiot- omy $^{14}$. Also maternal age over 25 years ${ }^{15}$ and maternal weight as well as the baby's head circumferenceareassociated factors ${ }^{14}$. N evertheless, some studies refute such statement as they have not found significant differences between the onset of $U I$ three months after delivery in women submitted to episiotomy or not ${ }^{16,17}$.

Hence, further comparative studies and those on groups of women submitted to episiotomy or not are required ${ }^{13}$. Studies on the physiopathological process of UI would also behelpful, since it is believed that such process is probably related to innervation damage and to changes in the physiological structure of the lower urinary tract $^{18,19}$

In view of the abovementioned facts, programs to encourage UI prevention for life and not only in the postpartum period are essential ${ }^{18}$, sincethere is scientific evidence showing that exercise practice for strengthening the pelvic floor muscles, if performed more frequently during pregnancy and the puerperium, decreases women's probability to present UI, regardless of delivery type ${ }^{20}$. It also considerably reduces the need for surgery ${ }^{21}$.

It is recommended that this type of exercise should be supervised by an expert continence physiotherapist or nurse and provided particularly to women at higher risk, such as after vaginal or by forceps delivery or with large newborns for gestational age ${ }^{22}$.

There is also pharmacological treatment available. It is beneficial in UI therapy and in improving quality of life; however, it does not benefit patients with depressive symptoms or with cognitive disorders. Additionally, it causes adverse effects, such as xerostomy, fatigue, constipation and hyperhidrosis ${ }^{23}$, and is less effective in older individuals due to age-related changes ${ }^{24}$.

In addition to the abovementioned conservative treatments, surgical procedures are possible, such as vaginal Kelly-Kennedy Urethrocystopexy, M arshall-M archetti-Krantz colpo-urethrocystopexy, Burch colpourethropexy and Stamey-Pereyra uretrocystopexy through a combined route under endoscopic control. There are also other techniques such as epidural injection of teflon, purified collagen, autologous adipose tissue, among other materials used to increase the urethral fold; and the use of pubovaginal slings with the replacement of endoscopic suspension for maintenance of the results from the performed treatment for a longer period of time ${ }^{25}$.

It is noteworthy that even women who re cover from incontinenceare not free of it because 
UI may recur two years after the surgery regardless of the surgical technique used, which is particularly truefor stress UI. These risk factors may be minimized with the concomitant treatment of pelvic floor muscle disorders, such as urge UI, advanced prolapse and or hormone therapy ${ }^{26}$.

Despite the technical and scientific development of UI therapy, women's access to it is still limited due to the lack of programs targeted at their health and, specifically at the problem. This situation is not peculiar only in the Brazilian scenario, but also in other countries that are considered to be developed.

The European country with the highest percentage of UI surgeries is the United Kingdom, with $8 \%$ of women operated for the problem, followed by Germany, with $5 \%$, and Spain and France, both with $3 \%{ }^{27}$.

Another problem reported by theliteratureas a barrier to $\mathrm{UI}$ treatment is that, despite the possibility of existing therapies, $50 \%$ of women discuss their incontinence problems, and only onethird of them receive some type of treatment, according to a study conducted in WashingtonUSA ${ }^{28}$.

Previous studies to the present investigation, which were conducted in European countries, report a small percentage of women who seek UI treatment: Spain: Spain (24\%), the United Kingdom (25\%), France (33\%) and Germany $(40 \%)^{27}$.

These facts have condemned women to managing their own urinary leakages in a silent and solitary fashion, by means of palliative strategies that are, many times, unsafe to their health, and among which the following are noteworthy: re fraining from social, leisure and religious activities that takelong periods of time, attending only places wheretoilets areavailable, using urinecollectors, refraining from taking anti-hypertension medicines when they go out, reducing the intake of liquids, taking sleeping pills, being careful when choosing clothes and about clothes changing frequency, avoiding coughing, sneezing and laughing.

It is also noteworthy that the increased frequency of UI-related comorbidities results from the delay in seeking treatment. A study conducted on French women with the purpose to evaluate the impact of UI on their quality of life observed that 58\% showed at least one complaint about their social life, followed by those related to sexuality, such as: feeling anxious when thinking about sexual activity; feeling that their sexual behavior has been affected; being concerned about leaking urine during the sexual act. Addi- tionally, work performance was affected in 38\% of the women, who interrupted their professional or house hold activities ${ }^{29}$.

The loss of self-confidence in women with UI results from insecurity in face of the moral and physiopsychosocial vulnerability to which they are exposed, according to the lived processthat emerged from their experiences: feeling morally depressed in experiencing $\mathrm{UI}$, affecting needs related to sleep and sexuality, theonset of UI-related complications, having health problemsthat worsen theexperience and entering psychic suffering.

An integrative literature review reports the negative impact of UI on women's psychosocial well-being asit makes them feel embarrassed, and as result, they stay away from social activities, which prevents them from going shopping and participating in physical activities, for instance, and leads them to abstain from their sexuality because they consider themselves to be less attractive ${ }^{24}$.

This author reports that women severely affected by UI are $80 \%$ more prone to suffer depression, whilethose with moderate and mild UI show a $40 \%$ rate when compared to continent individuals. UI is also associated with feelings of sadness and solitude. The increased severity of symptoms and frequency of incontinence episodes increase the level of annoyance ${ }^{27}$.

It can be added that women with more frequent episodes tend to consider the experienceto be a considerable disturbance in their lives while less frequent incontinence episodes occurring approximately once a month are not perceived as very problematic ${ }^{27}$.

The author also reports that the social embarrassment, caused by the aggravation of symptoms, perception of urine odor and the occurrence of humiliating accidents, is the determinant process of disturbance, and as result, they become worried about coughing and sneezing for fear of not timely reaching a toilet ${ }^{27}$.

In Brazil, the treatments provided by SUS, are usually surgical or drug-based. Physiotherapeutic treatments are most often provided by private health insurance coverage or by rehabilitation services at universities. This fact is in disagreement with the principles on which SUS is founded: universality, equity and integrality, and the lack of a specific conservative program for assisting women with $\mathrm{UI}$ is a fundamental problem, considering that it could contribute to improve part of the incontinence complaints and provide support to achieving cure ${ }^{30}$. 


\section{Final remarks}

The performance of this study, according to the methodological and theoretical frameworks adopted, allowed for achieving the objectives outlined as well as for furthering the understanding of the experience of women with UI.

From the analysis of the data in this study, it was possible to observe that the context experienced by Brazilian women with $\mathrm{UI}$ is similar to that of women in other countries in the American, European and Asian continents. It shows the perpetuation of women's suffering with a disease whose technical and scientific advancement is still not able to benefit most of them due to limited access to prevention and rehabilitation programs. However, it is believed that one of the greatest contributions from this study lies in the discovery of a theoretical model showing that such facts may be contributing to the weakening of young women's adhering to programs that encourage vaginal delivery.

Therefore, it shows the need to perform further studies whose focus is the social representation of $\mathrm{UI}$ by considering the program for vaginal delivery encouragement.

It points out the need to develop competencies related to UI clinical evaluation, diagnosis and treatment to educational institutions training health care professionals, and it shows the State the need to provide conditions so that such professionals can fully attend to women's needs.

Finally, it is believed that the main limitation in this study lies in the non-exploration of the experience of women with $\mathrm{UI}$ who are $\leq 40$ years old.

\section{Collaborators}

RCA Delarmelindo drafted the research project, performed the literature review and also participated in data collection, analysis and discussion. SCM Bocchi supervised the research and was involved from project design to manuscript formatting. RAP Rodrigues and CM GL Parada collaborated with writing the paper.

\section{Acknowledgment}

The authors are thankful to the São Paulo State Department of $\mathrm{H}$ ealth for providing financial support for the conduction of this study as a requirement from the Professional Master's Program in Nursing - Univ. Estadual Paulista (UNESP), Botucatu, Brazil. 


\section{References}

1. Abrams P, Cardozo L, Fall M, Griffiths D, Rosier $P$, Ulmsten U, van Kerrebroeck P, Victor A, Wein A. The standardization of terminology of lower urinary tract function: report from the standardization sub-committee of the International Continence Society. Neurol Urodyn 2002; 21(2):167-178.

2. Higa R, Lopes MHBM. The impact of urinary incontinence on female nursing personnel. Rev Bras Enf 2007; 60(2):213-216.

3. Thüroff JW, Abrams $P$, Andersson KE, Artibani W, Chapple CR, Drake MJ, Hampel C, Neisius A, Schröder A, Tubaro A. 2011. EAU guidelines on urinary incontinence. Eur U rol 2011; 59(3):387-400.

4. Wennberg AL, M olander U, Fall M, Edlund C, Peeker R, Milson I. A longitudinal population-based survey of urinary incontinence, overactive bladder, and other lower urinary tract symptoms in women. Eur U rol 2009; 55(4):783-791.

5. Long RM, Giri SK, Flood HD. Current concepts in female stress urinary incontinence. Surgeon 2008; 6(6):366-372.

6. Altman D, Forsman $M$, Falconer $C$, Lichtenstein $P$. Genetic influence on stress urinary incontinence and pelvic organ prolapse. Eur U rol 2008; 54(4):918-923.

7. Higa R, Lopes MHBM. Fatores associados com a incontinência urinária na mulher. Rev Bras Enferm 2006; 58(4):422-428.

8. Carpenito-M oyet LJ. Diagnósticos de enfermagem: aplicação à prática clínica. 10aㅡ Edição. Porto Alegre: Artmed; 2005.

9. Strauss A, Corbin J. Pesquisa qualitativa: técnica e procedimentos para o desenvolvimento de teoria fundamentada. Porto Alegre: Artmed; 2008.

10. Charon JM. Symbolic interactionism: an introduction, an interpretation, an integration. 3a Edição. New York: Prentice Hall; 1989.

11. Huebner M, Antolic A, Ralf T. The impact of pregnancy and vaginal delivery on urinary incontinence. Int J Gynaecol Obstet 2010; 110(3):249-251.

12. Nygaard I. U rinary incontinence: is cerarean delirery protective? Semin Perinatol 2006; 30(5):267-271.

13. Chang SR, Chen KH, Lin HH, Chao YMY, Lai YH. Comparison of the effects of episiotomy and no episiotomy on pain, urinary incontinence, and sexual function 3 months postpartum: a prospective follow-up study. Int J Nurs Stud 2011; 48(4):409-418.

14. Yang $X$, Zhang $H X, Y u Y H, G$ ao XL, Yang $H X$, Gong $Y$. The prevalence of fecal incontinence and urinary incontinence in primiparous postpartum Chinese women. Eur J of Obstet Gynecol Reprod Biol 2010; 152(2):214-217.

15. Rortveit G, Hunskaar S. U rinary incontinence and age at the first and last delivery: the Norwegian hunt/epincont study. Am J Obstet Gynecol 2006; 195(2):433-438.

16. Karacan Z, Euroglu K. Effects of episiotomy on bonding and mother's health. J Adv Nurs 2003; 43(4):384-394.

17. Sartore A, Seta F, Maso G, Pregazzi R, Grimaldi E, Guaschino $S$. The effects of mediolateral episiotomy on pelvic floor function after vaginal delivery. Obstet gynecol 2004; 103(4):669-673.
18. Whirford HM, Alder B, Jones M. A longitudinal follow up of women in their practice of perinatal pelvic floor exercises and stress urinary incontinence in north-east Scotland. M idwifery 2007; 23(3): 298-308.

19. Chaliha C. Postpartum pelvic floor trauma. Curr Opin Obstet Gynecol 2009; 21(6):474-479.

20. Rett MT, Simões JA, Herrmann V, Gurgel MSC, M orais SS. Qualidade de vida em mulheres após tratamento da incontinência urinária de esforço com fisioterapia. Rev. Bras Ginecol O bstet 2007; 29(3):134140.

21. Grau J, Pons ME, Arnau A, Estopiña N, Roura P. Incontinencia urinaria a los 2 meses pos parto: persistencia de los síntomas a los 6 y 12 meses. Prog Obstet Ginecol 2008; 51(5):271-280.

22. Price N, Dawood R, Jackson SR. Pelvic floor exercise for urinary incontinence: a systematic literature review. M aturitas 2010; 67(4):309-315.

23. Leeuwen JHS, Lange RR, Jonasson A F, Chen AF, Viktrup L. Efficacy and safety of duloxetine in elderly women with stress urinary incontinence or stresspredominant mixed urinary incontinence. M aturitas 2008; 60(2):138-147.

24. Viktrup L, Yalcin I. Duloxetine treatment of stress urinary incontinence in women: effects of demographics, obesity, chronic lung disease, hypoestrogenism, diabetes mellitus, and depression on efficacy. Eur J Obstet Gynecol Reprod Biol 2007; 133(1): 105-113.

25. Moreira ECH, Yasuda, KE, Kimura, FR. Tratamento cirúrgico e conservador da incontinência urinária de esforço. Fisioter mov 2001; 13(2):9-13.

26. Richter HE, Diokno A, Kenton K, Norton P, Albo $M, K$ raus S. Predictors of treatment failure 24 months after surgery for stress urinary incontinence. Jul 2008; 179(3):1024-1030

27. Lose $G$. The burden of stress urinary incontinence. Eur Urol Suppl 2005; 4(1):5-10.

28. Melville JL, Newton K, Fan MY, Katon W. Healt care discussions and treatment for urinary incontinence in U.S. women. Am J Obstet Gynecol 2006; 194(3):729-737.

29. Lassere $A$, Pelat $C$, Guéroult $V$, Hanslik T, ChartierKastler $\mathrm{E}$, Blanchon T, Ciofu C, Montefiore ED, Alvarez FP, Bloch J. Urinary incontinence in French women: prevalence, risk factors, and impact in quality of life. Eur Ass U rol 2009; 56(1):177-183.

30. Seleme MR. Incontinência urinária: um problema social de saúde pública [dissertação]. Rio de Janeiro: Universidade Federal do Rio Janeiro; 2006.

Artigo apresentado em 17/04/2012

Aprovado em 29/06/2012

Versão final apresentada em 23/07/2012 
